DOI : $10.14746 /$ rie.2021.15.25

\title{
Anna Pacześniak, Bartosz Rydliński (red.), Europejskie partie polityczne. Dyskurs programowy w Unii Europejskiej, Warszawa 2021, Wydawnictwo Sejmowe, ss. 302.
}

Wielowymiarowe zróżnicowanie programów i tożsamości, które firmują działające na płaszczyźnie Unii Europejskiej europartie oraz agenda dyskutowanych na poziomie Unii Europejskiej problemów i zadań w latach 2014-2019 znalazły odzwierciedlenie w opublikowanej przez Wydawnictwo Sejmowe i promowanej podczas specjalnego webinarium książki.

Atutem pracy jest dojrzałość zaprezentowanych wniosków, osnuta na zaawansowanych studiach poświęconych funkcjonowaniu partii politycznych oraz zastosowana metodologia, która została za każdym razem dostosowana do zgromadzonej przez autorów bazy źródłowej. We wprowadzeniu Anna Pacześniak i Bartosz Rydliński podkreślili: „,przedmiotem tej publikacji uczyniliśmy programowy dyskurs partii na poziomie europejskim" i zaznaczyli, że autorzy artykułów prezentujących ugrupowania polityczne odnosili się do genezy i ewolucji funkcjonowania grup politycznych w Unii Europejskiej, badali ich tożsamość i postrzeganie, a przede wszystkim analizowali manifesty polityczne i pozostałe źródła dokumentujące funkcjonowanie partii w latach 2014-2019. Dodatkowo autorzy zwrócili uwagę na działalność przedstawicieli partii politycznych, przede wszystkim jej liderów, którym powierzona została rola Spitzenkandidatów. Zakończenie pióra Anny Pacześniak i Bartosza Rydlińskiego ma natomiast na celu sprowokowanie rozważań nad znaczeniem i pozycją europejskich partii politycznych. W tym celu redaktorzy naukowi tomu zapytali, czy bliżej europejskim partiom politycznym do funkcji reżysera, pierwszoplanowanego aktora, czy statysty procesów integracji bądź dezintegracji europejskiej?

Monografia składa się z dwóch części. Pierwsza została przygotowana przez Radosława Zenderowskiego i Annę Pacześniak - dotyczy uwarunkowań i wyzwań funkcjonowania partii politycznych na poziomie europejskim. Druga część stanowi przegląd debat programowych europartii i frakcji politycznych w Parlamencie Europejskim. Według kolejności zaprezentowanych rozdziałów: Wojciech Gagatek przygotował rozdział dotyczący Europejskiej Partii Ludowej; Bartosz Rydliński i Paula Wiśniewska napisali o Partii Europejskich Socjalistów; Błażej Choroś o Porozumieniu Liberałów i Demokratów na rzecz Europy; Anna Skrzypek-Claassens o Europejskiej Partii Zielonych; Beata Kosowska-Gąstoł o Sojuszu Konserwatystów i Reformatorów w Europie; Bartosz Rydliński o Partii Europejskiej Lewicy, a Natasza Styczyńska i Elodie Thevin o Sojuszu Europejskich Ruchów Narodowych i Wolności. Każdy z tytułów rozdziałów opatrzony jest hasłem, które kieruje czytelnika do tez zaprezentowanych w trakcie oceny funkcjonowania europartii. Europejska Partia Ludowa jest badana przez pryzmat funkcjonowania demokracji 2.0, Partia Europejskich Socjalistów z perspektywy znanych definicji „trzeciej drogi” i ich ukierunkowania na współczesne wyzwania. W ocenie funkcjonowania Porozumienia Liberałów i Demokratów na rzecz Europy autor ocenił, że partia stosuje taktykę korzystania z sytuacji: „gdzie dwóch się bije, tam trzeci korzysta”. Europejska Partia Zielonych została zauważona jako polityczny trendsetter na terenie Unii Europejskiej, a Sojusz Konserwatystów i Reformatorów w Europie jako ugrupowanie, które oscyluje między federacją europejską a likwidacją Unii Europejskiej. W końcu Partia Europejskiej Lewicy została zdefiniowana jako ugrupowanie ideowe, a Sojusz Europejskich Ruchów Narodowych i ruch na rzecz Europy Narodów i Wolności jako antagoniści integracji europejskiej. 